\title{
Do the media set the parliamentary agenda? A comparative study in seven countries
}

\author{
RENS VLIEGENTHART, ${ }^{1}$ STEFAAN WALGRAVE, ${ }^{2}$ FRANK R. BAUMGARTNER ${ }^{3}$ \\ SHAUN BEVAN,${ }^{4}$ CHRISTIAN BREUNIG,${ }^{5}$ SYLVAIN BROUARD,${ }^{6}$

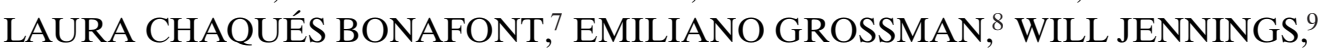 \\ PETER B. MORTENSEN,${ }^{10}$ ANNA M. PALAU ${ }^{11}$ PASCAL SCIARINI ${ }^{12}$ \\ \& ANKE TRESCH ${ }^{13}$ \\ ${ }^{1}$ University of Amsterdam, Netherlands; ${ }^{2}$ University of Antwerp, Belgium; ${ }^{3}$ University of North Carolina, \\ Chapel Hill, NC, USA $;{ }^{4}$ University of Edinburgh, UK, ${ }^{5}$ University of Konstanz, Germany; ${ }^{6}$ CEVIPOF, \\ Sciences Po, France, ${ }^{7}$ University of Barcelona and IBEI, Spain; ${ }^{8}$ Sciences Po Paris, France $;{ }^{9}$ University of \\ Southampton, UK; ${ }^{10}$ Aarhus University, Denmark; ${ }^{11}$ University of Barcelona, Spain; ${ }^{12}$ University of Geneva, \\ Switzerland; ${ }^{13}$ University of Lausanne, Switzerland
}

\begin{abstract}
A growing body of work has examined the relationship between media and politics from an agenda-setting perspective: Is attention for issues initiated by political elites with the media following suit, or is the reverse relation stronger? A long series of single-country studies has suggested a number of general agenda-setting patterns but these have never been confirmed in a comparative approach. In a comparative, longitudinal design including comparable media and politics evidence for seven European countries (Belgium, Denmark, France, Netherlands, Spain, Switzerland and the United Kingdom), this study highlights a number of generic patterns. Additionally, it shows how the political system matters. Overall, the media are a stronger inspirer of political action in countries with single-party governments compared to those with multiple-party governments for opposition parties. But, government parties are more reactive to media under multiparty governments.
\end{abstract}

Keywords: agenda-setting; comparative research; media; parliamentary questions; political systems

\section{Introduction}

Do the mass media exert political influence? For a long time scholars have examined the impact of media coverage on citizens. Until a decade or two ago, empirical research about the direct impact of mass media on what political elites or actors do was rare. Recently, research has picked up and studies on media and politics are on the rise. Mediatisation theory has become one of the common accounts in the area of media and politics (e.g., Altheide \& Snow 1979; Mazzoleni \& Schulz 1999; Strömback 2008; Esser \& Strömbäck 2014). It deals with how the political system and actors increasingly adapt to the media logic. Another growing body of work examines the relationship between media and politics from an agenda-setting perspective (e.g., Walgrave \& Van Aelst 2006). Agenda-setting scholars turn the matter of media power into a question of who leads and who follows regarding the issues that are discussed in the media and in the political realm. Is attention for issues initiated by political elites and do the media follow suit, or are the media the ones who initiate issue attention and is it the political elites that react afterwards? We know that the attention to issues is a 
crucial political resource, as classic (e.g., Bachrach \& Baratz 1962) and more recent accounts (e.g., Jones \& Baumgartner 2005) of politics and policy have taught us.

The growing literature on the agenda-setting influence of the media points to a number of patterns. A long series of single-country studies suggests that the media may set the agenda of politics more than the other way around (e.g., Kleinnijenhuis \& Rietberg (1995), using Danish data); that the media matter more for symbolic than for substantial political initiatives (e.g., Walgrave et al. (2008), using Belgian data); that negative news sparks more political reaction than positive news (e.g., Thesen (2013), using Danish data); that the agenda of opposition parties is more determined by the media than that of government parties (e.g., Green-Pedersen \& Stubager (2010), using Danish data); that politics is more reactive to media coverage when it comes to foreign policy issues (e.g., Wood \& Peake (1998), with American data); or that, more generally, the media's agenda-setting influence varies across issue types (e.g., Soroka (2002), with Canadian data). Some of these single-country findings have been confirmed through other country studies, but most have not.

Although all available work seems to suggest that the media matter somehow for the political agenda, we still lack basic, generic knowledge about the media's agenda-setting influence that occurs in many or most countries. The single country character of the majority of studies means that we do not know to what extent findings hold in a crossnational perspective and how political agenda-setting might differ across countries. This study sets out to fill that void. Research examining the behaviour of political actors and systematically linking it to media content data in a comparative perspective has been rare to nonexistent (we know only of three exceptions: Van Noije et al. 2008; Vliegenthart \& Walgrave 2011b; Vliegenthart \& Mena Montes 2014). In a comparative, longitudinal design including comparable media and politics evidence for seven European countries and employing integrated analyses, this study highlights a number of generic patterns. Added to that, we show that political systems matter and that the media's political agenda-setting role differs across countries in a predictable way. Indeed, beyond testing the robustness of existing single-country findings, the main goal of the study is to theorise and examine how a political system's characteristics moderate the influence of the mass media on the political agenda. We consider one of the most defining characteristics of a polity - whether its government is typically composed of one or multiple parties - and argue that the agendasetting role of the media is larger in countries with a single-party government.

Concretely, we find that, in general and across the seven countries under study, the media matter more for politics than vice versa. Second, we corroborate previous studies by highlighting that opposition parties are more sensitive to media coverage than government parties. Third, government and opposition parties react very differently on media coverage under single-party compared to multiparty government. Opposition parties are even more reactive to media cues when the government they are challenging consists of only one party. Government parties do just the opposite: it is rather under a multiparty government that they devote more attention to issues after these have been covered in the media.

\section{The agenda-setting role of the media}

Extant work on the agenda-setting role of the mass media has found that the media do affect the parliamentary agenda. Not all, but most single-country studies find that media coverage 
for an issue leads to subsequent issue adoption by parliament (for an early overview, see Walgrave \& Van Aelst 2006). The finding applies to behavioural studies typically associating content analyses of parliamentary records and media stories. The same findings are even stronger when looking at the studies that draw on surveys with MPs. When asked directly, most MPs concur with the view that the media are important agenda-setters of their daily business in parliament (Walgrave 2008; Van Aelst \& Walgrave 2011; Midtbø et al. 2014). The reason for the media's significant agenda-setting role is that they form a formidable source of information, not only for ordinary citizens but also for political elites. Elites draw on other sources of information as well, but from the media they can learn about societal problems and the available solutions (Vliegenthart et al.2013), about public opinion (Herbst 1998) and about other elites' plans and actions (Davis 2007, 2009). The mere fact that an issue gets media attention gives its more informational weight and increases the chances of political fallout (Wolfe 2012). So, media coverage of issues is informative and often relevant for elites. This perceived importance of media for political actors is also one of the key observations in the literature on mediatisation. While mediatisation scholars assume a broader and more profound impact of media on politics (Strömbäck 2008), agenda-setting is a clear (and measurable) signal of the increased importance of media (Van Aelst et al. 2014).

Although there seems to be a growing consensus among students of political agenda-setting (and beyond) that the media affect the political agenda, only a few studies have actually compared the mutual influence of media and politics (these studies are: Kleinnijenhuis \& Rietberg 1995; Bartels 1996; Edwards \& Wood 1999; Walgrave et al. 2008). Most likely, the direction of the agenda-setting effect varies across the type of political agenda one is talking about. Agenda scholars have distinguished 'symbolic' from 'substantial' political agendas (Pritchard \& Berkowitz 1993; Walgrave \& Van Aelst 2006). The first refer to the political game and discourse in the political arena; the second to the actual policies and decisions made by policy makers. This study deals with parliamentary questions, which are a prototypical example of a symbolic activity. They do not have direct policy consequences and they do not announce policy or necessarily initiate it. Rather, questions are verbal skirmishes between political actors only loosely connected to policy making. Though media might have a short-term interest in the conflicts between political actors as indicated by the questions, we do not anticipate a large impact of questions on the media. Inversely, we do argue that the media form an important source of information for politicians. The media are like search engines constantly producing signals from society. They produce a continual stream of short, non-technical, problematising, ready-to-use and pre-interpreted bits of information that nurture elites' activities. Media act as an unremitting screening device injecting information into the political system. The opposite is not the case for parliamentary questions and their information value for the news media; questions most of the time do not contain new information, but repeat routinised stand-offs between incumbents and challengers. This brings us to our first hypothesis.

H1: The mass media's agenda-setting influence on parliamentary questions is larger than the opposite influence.

One of the few things that have been confirmed in several countries is the greater impact of the mass media on the questions opposition MPs are asking compared to those put by 
coalition MPs (Green-Pedersen \& Stubager 2010; Thesen 2013; Vliegenthart \& Walgrave 2011b). The reason is straightforward: the type of information that the media provide lends itself more to oppositional behaviour in parliament than to buttressing the government's initiatives. Mass media coverage has been found to be dealing with the negative, the problematic and the controversial (Soroka 2014; Baumgartner \& Chaqués-Bonafont 2015). A long tradition in news value and news selection, for example, has found that negative news prevails (Lengauer et al. 2012). And, additionally, news makers tend to frequently use a responsibility attribution frame looking for the person or organisation 'guilty' of a certain problem or accident (Semetko \& Valkenburg 2000; Thesen 2013). This type of information, naturally, is more appropriate for opposition than for government parties. It is the opposition's duty to oppose and to challenge the government however they can, while the media provide just what it needs. We expect this fundamental dynamic of the opposition using the media more often to be the case in as good as all countries and, therefore, formulate our second hypothesis

H2: The mass media's agenda-setting influence on parliamentary questions is larger for opposition than for government parties.

\section{Political systems moderate the political agenda-setting role of the media}

Our first ambition in this study is to replicate extant single-country studies and testing on seven countries whether what we know from case studies applies more generally. However, and more importantly, we also aim to produce new knowledge by, for the first time, providing a comparative account and putting forward expectations about differences in the media's agenda-setting role across countries. We argue that the media matter more for parliamentary questions in some countries than in others. While the data we draw upon may seem vast, the number of countries studied is only seven. This seriously reduces the study's analytical power. Therefore, we focus on just a single political system feature, but a very crucial and far-reaching one, we believe. We argue that the number of parties in government significantly moderates the media's role in determining the parliamentary agenda. In the comparative literature on majoritarian versus consensus democracies, coalition size is one of the crucial variables (Lijphart 1999). Coalition governments are of a different make-up than singleparty governments, and this also affects how the opposition behaves (Blondel \& MüllerRommel 1993). Our argument is that the size of the government acerbates the general differences between opposition and government parties in their responsiveness to media cues that we hypothesised above.

Single-party government increases the accountability of the government party. In multiparty governments, in contrast, responsibility is blurred, decision making is opaque and all coalition parties share responsibility for government actions. Who is to blame for what, and who can claim credit for what, is harder to make out. A single-party government to some extent eases the task of the opposition parties. They have a clear target that can be challenged without having to take into account the fine intricacies of how responsibilities among the government parties are divided. The increased clarity enables the opposition to rely on all possible means to destabilise and attack the government, and this implies that media coverage can be used intensely - knowing that a good deal of media coverage 
is negative, conflictual and targeting those responsible for what goes wrong. Additionally, under single-party government, the opposition may have less alternative information at its disposal with which to attack the government. As power is typically more concentrated in single-party government systems, this means that information about government affairs is scarcer. Indeed, students of comparative governments have used the concept of 'information asymmetry' to describe the unequal relationship between parliament and government, arguing that the government, and even government MPs, have privileged access to many sources of information (e.g., executive agencies, scientific advise) that opposition MPs lack (see, e.g., Saalfeld 2003). In some countries, information-sharing by the government is more institutionalised than in others and there is some work suggesting that this would be related to single-party versus multiparty government systems (e.g., Sprungk 2010). In sum, as a consequence of the increased information asymmetry under single-party government, we expect opposition members to use the media more to nurture their parliamentary war with the government.

H3: The mass media's agenda-setting influence on parliamentary questions is larger for opposition parties in countries with single-party government than in countries with multiparty government.

Second, the exact opposite argument applies to the government party when it is in government alone. Compared to a situation with several parties in government, we expect government party MPs to steer more away from issues covered in the media, as media coverage - negative and conflictual - plays on the strength of the opposition and tends to highlight governments' failures instead of its successes. In a multiparty government, in contrast, MPs from the government parties may still use media-cued questions to tease, press or tickle co-governing parties. In a single-party government all criticism of the government, derived from media coverage, unavoidably boils down to an attack on its own party. Also, the government-opposition information asymmetry that we expect to be larger under singleparty rule makes government MPs better informed when a single party is in government, thereby reducing these MPs' dependence on media coverage to feed their parliamentary action.

H4: The mass media's agenda-setting influence on parliamentary questions is smaller for government parties in countries with single-party government than in countries with multiparty government.

\section{Methods and cases}

We study the political agenda-setting process in seven European countries: the United Kingdom, Spain, France, Belgium, Netherlands, Denmark and Switzerland. These countries have been chosen because they represent a variety of European countries covering a diversity of political systems and because evidence from these countries was available. The first three countries are generally considered to be majoritarian democracies with a single- (or few-) party government. For the period under investigation, the United Kingdom is the prototypical case of single-party government characterised by the alternation in power of Conservatives and Labour (Lijphart 1999). Spain also shares most of the features of 
majoritarian democracies in terms of concentration of power in the executive, one dominant opposition party and a single-party government. While France formally is a multiparty system, there are two stable coalitions with major leading parties that alternately form the national government. We classify the United Kingdom, Spain and France as having a singleparty government. The four other countries in the study are often defined as 'consensus democracies', characterised by coalition governments formed by several coalition partners who engage in permanent negotiation (Lijphart 1999). For most of the research period, Belgium and the Netherlands have had a majority cabinet consisting of at least three parties sharing responsibility, while in Denmark there is a two-party minority government, which in many ways operates as a coalition majority cabinet. Switzerland has a system sui generis with a government that is more or less a mirror of the multiparty parliament. While we acknowledge that our distinction between single-party and multiparty government systems is rather crude - there probably also is a good deal of variation on the party level, there are degrees in the 'multipartyness' of the multiparty governments in our sample, and some countries (e.g., France), could also be classified as mixed cases - we think that with only seven cases it is best to keep the set-up as simple and straightforward as possible. The seven countries studied here provide us with a fair sample of party systems in Western democracies and with a good deal of political system variation. An additional reason to select these countries is that data on parliamentary activities and media coverage are available for them through the Comparative Agendas Project (CAP).

The study covers media and parliamentary questions in the seven countries during the past two decades. Research periods differ somewhat per country, depending on data availability: United Kingdom, 1997-2008; Spain, 1996-2011; France, 1995-2005; Netherlands, 1995-2011; Belgium, 1999-2008; Denmark, 1995-2003; and Switzerland, 19952003. Although the research periods in the seven countries are not identical, we believe this should have limited or no effect on the results. Period differences are small and there is only limited evidence of the media's effect on the political agenda as having changed over time (see, e.g., Vliegenthart \& Walgrave 2011a). We test for whether only including the months that we have data for all the countries in the analysis alters the results. The CAP databases are produced by coordinated efforts by national teams coding a wide range of political documents for the main topic that is discussed. More information about procedures and the codebook is available at the website www.beta.comparativeagendas.com.

In terms of questions, for the United Kingdom, Spain, Belgium and France we rely on oral questions; for the Netherlands, Denmark and Switzerland we use written questions. In the Netherlands, a random sample of 500 questions per parliamentary year was coded (roughly 30 per cent of the total number of questions). In all other countries, all questions were coded. Overall, a total of 97,634 parliamentary questions were coded. Procedures of how to ask questions differ across countries, but in each country the number of questions that can be asked is limited (especially the oral questions). This means that parties have to make trade-offs and that MPs are constrained in asking questions. In some countries like the United Kingdom ${ }^{1}$ and Denmark mainly opposition parties ask questions, in a country like Belgium government MPs are almost as active question-wise, while in Spain the government-opposition ratio varies over time depending on the varying formal rules. In Switzerland, traditionally having coalitions that consist of all major parties, the majority of questions are asked by government parties. 
Table 1. Descriptive statistics (major topics)

\begin{tabular}{lcc}
\hline Topic & Media & Parliamentary questions \\
\hline Macroeconomics & 0.0448 & 0.0526 \\
Civil rights and liberties & 0.0400 & 0.0281 \\
Health & 0.0425 & 0.0777 \\
Agriculture and fishery & 0.0141 & 0.0311 \\
Labour and employment & 0.0301 & 0.0379 \\
Education & 0.0284 & 0.0422 \\
Environment & 0.0134 & 0.0301 \\
Energy & 0.0118 & 0.0167 \\
Immigration and integration & 0.0197 & 0.0313 \\
Transportation & 0.0394 & 0.0663 \\
Law, crime and family issues & 0.1153 & 0.0899 \\
Social welfare & 0.0091 & 0.0337 \\
Community development, planning and housing & 0.0096 & 0.0228 \\
Banking, finance and domestic commerce & 0.0519 & 0.0343 \\
Defence & 0.0601 & 0.0457 \\
Space, science, technology and communications & 0.0318 & 0.0197 \\
Foreign trade & 0.0069 & 0.0066 \\
International affairs and foreign aid & 0.0806 & 0.0553 \\
Government operations & 0.1415 & 0.0912 \\
Public lands and water management & 0.0047 & 0.0077 \\
\hline
\end{tabular}

Notes: Immigration and integration are included in civil rights and liberties for Spain and the United Kingdom. Denmark is excluded here because of different issue classification.

For the media data, we use country level codings of front-page coverage of one or two newspapers - again following the methodology of the CAP project. All newspapers included in the analyses are widely read quality broadsheets. For the United Kingdom The Times was coded (only the Wednesday front page), for Spain El Pais and El Mundo, for Belgium De Standaard, for the Netherlands NRC Handelsblad and De Volkskrant (13 per cent sample stratified by year), for Switzerland Neue Zürcher Zeitung, and for France Le Monde. In the Danish case, newspaper data were not available and media attention was measured using the Danish radio news twice daily, when long versions of the hourly radio news are broadcast (at noon and $6.30 \mathrm{pm}$ ). These broadcasts are argued to be representative of the larger media environment (Green-Pedersen \& Stubager 2010). The fact that in Denmark radio news was used and not newspapers does not make any difference; excluding the Danish case from the analyses did not change the results. Overall, over 171,434 newspaper articles and 74,428 radio items are coded.

All stories and parliamentary questions were coded following the comparative agendas codification schemes. This means we classified all stories on the front pages and all oral (and written) questions introduced by political parties across 19 or 20 major topics (see Table 1 for descriptive statistics), with each agenda item given one topic code. For the questions, we use the party variable to identify whether the political party was part of the government 
or not. ${ }^{2}$ For the coding of the Danish radio broadcasts and parliamentary questions a slightly different codebook was used resulting in somewhat different issue categories. Table 1 summarises the relative salience of the major topics that are included in the analysis on the media and the questions agenda.

To test the mutual dependency of media and parliament, we rely on pooled time-series models, with months pooled in a combination of country and issue categories. The main variables are the relative share of attention devoted to an issue in parliamentary questions and media per month. We rely on monthly level analysis, because (a) we assume influences take place at short time intervals (previous work has argued, and found, that the political reaction to the media (or vice versa) is either immediate or absent; see, e.g., Walgrave et al. 2008); and (b) lower aggregation levels would result in too low values and too many zeros on the main variables (see also Van Noije et al. 2008; Vliegenthart \& Roggeband 2007).

We conduct three analyses. For all analyses, we report ordinary least squared (OLS) regression models with panel corrected standard errors (PCSE) (Beck \& Katz 1995). The structure of our data requires specific attention for two issues: autocorrelation and heterogeneity. To deal with autocorrelation all our models include a lagged dependent variable (t-1). Additionally, we account for seasonal effects by including the value at $\mathrm{t}-12$. Heterogeneity (i.e., differences in attention across issues and countries that are not captured by the substantive independent variables in our model) is accounted for by those lagged values as well. Furthermore, our data show contemporaneous correlation for both parliament and media (Breusch-Pagan test after fixed effects models), which means that scores in the same month correlate across countries and issues. These characteristics make OLS with PCSE a viable strategy for analysis. We additionally estimated the analyses using feasible generalised least squares (FGLS). Results are comparable to the OLS-PCSE results. Alternative modeling strategies are discussed in the Appendix.

In the first analysis, we assess effect sizes and the mutual dependency between media and questions. In the second analysis, we assess differences across countries in the effect media have on parliamentary questions, and we estimate models where we include a dummy variable that indicates whether a country has a single-party government (1) or not (0). The interaction term between media attention/parliamentary questions and the single-party government dummy captures the potentially differential impact of media on questions and questions on media. In the third analysis, we test whether effects of media on politics differ for opposition and government parties. These analyses include the parliamentary questions for opposition and government parties as separate variables. Denmark is excluded from this analysis, since in this country government parties hardly ask any questions.

\section{Results}

We first look at the overall mutual relationship between media coverage and parliamentary questions. The results of the OLS models confirm the existence of mutual dependencies: the lagged value of media has a positive and significant effect on parliamentary questions: a 1 per cent increase in media attention for an issue results in a 0.126 per cent increase 
Table 2. Mutual dependencies between media and parliamentary questions (OLS-PCSE)

\begin{tabular}{lcc}
\hline & Unstandardised & Standardised \\
\hline Media attention $_{\mathrm{i}, \mathrm{t}}$ & & \\
Media attention $_{\mathrm{i}, \mathrm{t}-1}$ & $0.579^{* * * *}(0.015)$ & 0.579 \\
Media attention $_{\mathrm{i}, \mathrm{t}-\mathrm{2}}$ & $0.319^{* * * *}(0.015)$ & 0.319 \\
Parliamentary questions & 0.030 \\
Constant & $0.029^{* * * *}(0.006)$ & \\
$\mathrm{R}^{2}$ & $0.003^{* * *}(0.000)$ & \\
Parliamentary questions $_{\mathrm{i}, \mathrm{t}}$ & 0.734 & 0.273 \\
Parliamentary questions $_{\mathrm{i}, \mathrm{t}-1}$ & & 0.274 \\
Parliamentary questions $_{\mathrm{i}, \mathrm{t}-12}$ & $0.273^{* * * *}(0.017)$ & 0.124 \\
Media attention $_{\mathrm{i}, \mathrm{t}-1}$ & $0.275^{* * * *}(0.016)$ & \\
Constant & $0.126^{* * * *}(0.011)$ & \\
$\mathrm{R}^{2}$ & $0.013^{* * * *}(0.001)$ & \\
\hline
\end{tabular}

Notes: ${ }^{* * *} \mathrm{p}<0.001 . \mathrm{N}=17,844$.

in attention for that issue in parliament. The reverse effect is also present: a 1 per cent increase in parliamentary questions results in a 0.029 per cent increase in media attention. Standardised and unstandardised coefficients are largely similar, since the unstandardised scores are already relative ones. Alternative specifications yield similar results. The effect of media on parliament is clearly stronger than the effect of parliament on media (the difference in effect size is 0.097 with a standard error of $0.013, \mathrm{p}<0.001$ ). These results are in line with $H 1$, which predicted a stronger effect of media on questions than vice versa (see Tables 2 and 3).

$H 2$ held that the opposition's questions would be more affected by preceding media coverage than the government's questions. Here, we compare two models: one that has questions from the opposition as a dependent variable, and one that has questions from the government parties as a dependent variable. In both instances, we control for the questions asked in the month before and one year earlier. The results as displayed in Table 3 confirm the hypothesis: for government parties, a 1 per cent increase in media attention results in a 0.067 per cent increase in parliamentary attention. For opposition parties this effect is twice the size: 0.134 per cent. The difference is significant (difference is 0.067 with a standard error of $0.017, \mathrm{p}<0.001)$. The results furthermore reveal that the effect of opposition questions on media attention does not differ significantly from the effect of questions posed by government parties (difference is $0.052, \mathrm{Chi}^{2}=0.032, \mathrm{df}=1, \mathrm{p}=0.57$ ). Again, alternative modelling strategies yield similar conclusions.

Table 4 presents the results of two models that deal with the comparison between countries with a single-party government and countries with a multiparty government. The main effects model again confirms that media attention in general has a considerable impact on parliamentary questions $(0.127)$. The second interaction effects model shows that the interaction between single-party government and media attention is positive (0.039), but it does not reach significance. It is not the case that, in general, media impact on parliamentary questions is larger under single-party compared to under multiparty governments. 
Table 3. Mutual dependencies between media and parliamentary questions for opposition and coalition parties (OLS-PCSE)

Unstandardised

$$
\begin{gathered}
0.565^{* * *}(0.015) \\
0.303^{* * *}(0.015) \\
0.020^{* *}(0.006) \\
0.014^{* *}(0.005) \\
0.004(0.000) \\
0.667
\end{gathered}
$$

Standardised

Media attention ${ }_{i, t}$

Media attention ${ }_{i, t-12}$

Opposition questions i,t-1

Government questions $\mathrm{i}, \mathrm{t}-1$

Constant

$\mathrm{R}^{2}$

Opposition questions $\mathrm{i}_{\mathrm{i}, \mathrm{t}}$

Opposition questions i,t-1

$0.232^{* * * *}(0.016)$

0.232

Opposition questions $\mathrm{i}, \mathrm{t}-12$

Government questions i,t-1

$0.211^{* * *}(0.015)$

0.211

$0.070^{* * * *}(0.010)$

0.075

Government questions $\mathrm{i}, \mathrm{t}-12$

$0.111^{* * *}(0.010)$

0.120

Media attention $\mathrm{i}, \mathrm{t}-1$

Constant

$\mathrm{R}^{2}$

$0.134^{* * *}(0.013)$

$0.008(0.001)$

0.248

Government questions $\mathrm{i}_{\mathrm{i}, \mathrm{t}}$

Government questions $\mathrm{i,t}-1$

$0.149^{* * * *}(0.013)$

0.149

Government questions i,t-12

$0.187^{* * *}(0.013)$

0.187

Opposition questions $\mathrm{i}, \mathrm{t}-1$

$0.119^{* * *}(0.011)$

0.110

Opposition questions $\mathrm{i}, \mathrm{t}-12$

$0.134^{* * *}(0.011)$

0.123

Media attention $\mathrm{i,t-1}$

$0.067^{* * * *}(0.011)$

0.060

Constant

$\mathrm{R}^{2}$

\begin{tabular}{|c|c|c|}
\hline Parliamentary attention $_{i, t}$ & Main effects model & Interaction effects model \\
\hline Parliamentary questions $\mathbf{i , t - 1}$ & $0.273^{* * *}(0.007)$ & $0.272^{* * *}(0.007)$ \\
\hline Parliamentary questions ${ }_{i, t-12}$ & $0.275^{* * *}(0.007)$ & $0.275^{* * * *}(0.007)$ \\
\hline Media attention $_{\mathbf{i}, \mathrm{t}-1}$ & $0.127^{* * *}(0.007)$ & $0.113^{* * *}(0.008)$ \\
\hline Single-party (SP) government & $-0.001(0.001)$ & $-0.003^{* *}(0.001)$ \\
\hline Media $_{\mathbf{i}, \mathrm{t}-1} *$ SP government & & $0.039(0.024)$ \\
\hline Constant & $0.014^{* * * *}(0.001)$ & $0.014^{* * * *}(0.001)$ \\
\hline $\mathrm{R}^{2}$ & 0.252 & 0.253 \\
\hline
\end{tabular}

$0.014^{* * *}(0.001)$

0.175

Notes: ${ }^{* * *} \mathrm{p}<0.001 ;{ }^{* *} \mathrm{p}<0.01 . \mathrm{N}=15,719$.

Table 4. Differential impact of media on parliamentary questions across party systems (OLS with PCSE model)

Notes: ${ }^{* * *} \mathrm{p}<0.001 ;{ }^{* *} \mathrm{p}<0.01 . \mathrm{N}=17,844$. 
Table 5. Differential impact of media on parliamentary questions across party systems for opposition and government parties (OLS with PCSE model)

\begin{tabular}{|c|c|c|}
\hline Parliamentary attention $_{i, t}$ & Opposition parties & Government parties \\
\hline Parliamentary attention $_{\mathrm{i}, \mathrm{t}-1}$ & $0.276^{* * *}(0.016)$ & $0.202^{* * *}(0.014)$ \\
\hline Parliamentary attention $_{\mathbf{i}, \mathrm{t}-12}$ & $0.267^{* * *}(0.016)$ & $0.244^{* * *}(0.014)$ \\
\hline Media attention $_{i, t-1}$ & $0.104^{* * * *}(0.009)$ & $0.149^{* * * *}(0.015)$ \\
\hline Single-party (SP) government & $-0.004^{* * *}(0.001)$ & $0.005^{* * * *}(0.001)$ \\
\hline Media $_{i, t-1}{ }^{*}$ SP government & $0.053^{*}(0.026)$ & $-0.078^{* * *}(0.020)$ \\
\hline Constant & $0.013^{* * *}(0.001)$ & $0.015^{* * *}(0.001)$ \\
\hline $\mathrm{R}^{2}$ & 0.240 & 0.148 \\
\hline
\end{tabular}

Notes: ${ }^{* * *} \mathrm{p}<0.001 ;{ }^{* *} \mathrm{p}<0.01 ;{ }^{*} \mathrm{p}<0.05 . \mathrm{N}=17,844$ (for opposition parties) and 15,719 (for government parties, due to the fact that in Denmark government parties hardly ask any questions).

We hypothesised that opposition parties especially would be more reactive to media coverage under single-party government rule (H3) whereas government parties would display the exact opposite pattern with more media reactivity in countries with multiparty governments (H4). We test this by comparing media effects on questions asked by opposition parties and government parties. Table 5 presents the results and confirms both our hypotheses. For opposition parties, the effect of media coverage on parliamentary questions is larger in the case of a single-party government (positive interaction term: 0.053). For government parties, it is actually smaller (negative interaction term: -0.078 ). This demonstrates that in single-party government situations the governing party feels a weaker necessity to respond to media coverage than when there is a multiparty government.

Figure 1 provides an additional graphical presentation of the difference for opposition and government parties. Figure 1a shows that differences for opposition parties across countries with different types of government are small. This is also reflected by the coefficient (0.053) that is only significant at the 0.05 level. Still, adding the interaction term results in significant model improvement. Figure $1 \mathrm{~b}$ does the same for government parties, finding more substantial differences between such parties under single-party versus multiparty rule.

\section{Robustness checks}

We conducted various additional analyses to check the robustness of our results. First of all, we have different time periods available for each single country. We repeated all analyses for the period for which we have data for all countries (February 1999 until September 2003) to ensure that results are unaffected by the varying time periods. The replication of all analyses $(\mathrm{N}=7,788$ for the first analysis, and 6,388 for analyses that focus on the governmentopposition distinction) show that results are largely similar to the ones on the full dataset. In many instances, effect sizes are even somewhat larger. There are two small deviations. First, there is an overall significant interaction effect of single-party government and media coverage on the whole parliamentary agenda, while this effect is (only just) not significant in the full sample analysis. Second, the interaction of single-party government and media 

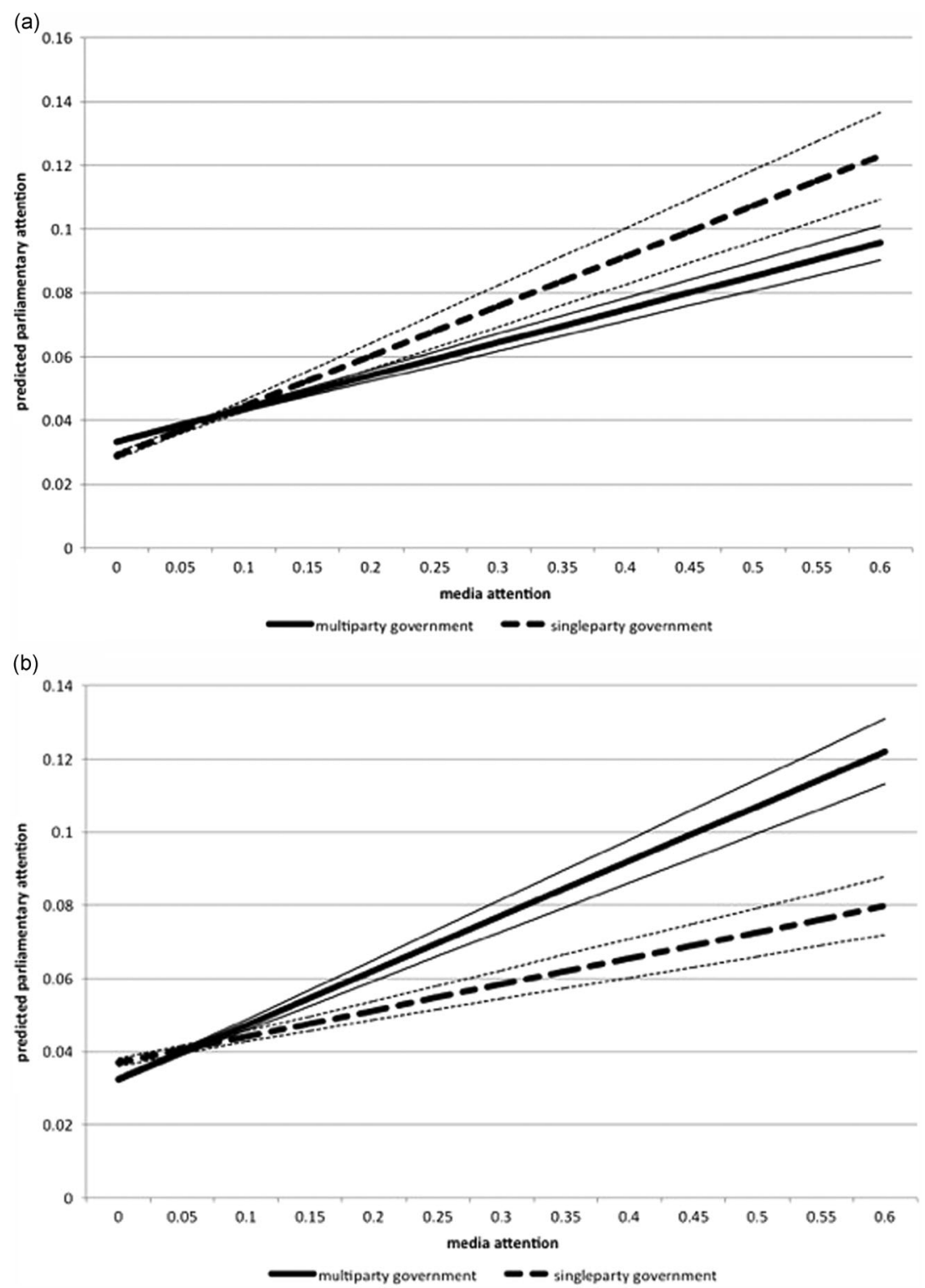

Figure 1. Effects of media coverage on parliamentary questions for opposition (a) and government (b) parties under different types of government.

coverage on the government agenda is only marginally significant $(\mathrm{p}=0.08)$, while it is significant in the full sample analysis.

A second robustness check concerns analyses at the country level. If we conduct the analyses separately for each individual country, we largely confirm the main findings from the pooled analysis. First, the effect of media on parliament is positive and significant in six out of seven countries (France being the exception), while the effect of parliament on media is only significant in four out of seven countries (Belgium, Spain, United Kingdom and 
Switzerland). In all instances, the coefficient of the effect of media on parliament is larger than the coefficient of the effect of parliament on media. This is in line with the pooled analysis and the first hypothesis.

Second, in line with the findings from the pooled analysis, we find no difference in the effects of the government agenda and the opposition agenda on the media agenda in five of the six countries (Denmark is excluded because government parties hardly ask any questions). Only in Switzerland do we find a larger impact of questions asked by the government parties than those asked by opposition parties $(\mathrm{p}=0.04)$.

Third, for two countries (Belgium and Spain), we find that the effect of the media agenda is significantly larger on the opposition agenda than on the government agenda. For the other countries, the difference is not significant. This result is a partial confirmation of $H 2$ and qualifies the findings from the pooled analysis to some extent. Still, overall, the countrylevel findings are largely in line with those of the pooled analysis. ${ }^{3}$

\section{Conclusion}

The goal of this article was twofold. First, we wanted to test to what extent the findings of previous single-country studies regarding the media's influence on the parliamentary agenda travel to other countries and are thus generic and robust. Second, our aim was to innovate by putting forward and testing new hypotheses about the varying political agenda-setting influences of the media in different countries. With regard to the first aim, we can be short. We found the media to generally matter. Interestingly, the media seem to be more inspiring for questioning than that questions seem to elicit media attention for the underlying issue. Additionally, several studies have already suggested that opposition parties take their cues more readily from the media than government parties; we can confirm that this is more generally the case indeed. Media matters more for the opposition.

Considering our second goal, we believe we have offered new evidence and plausible explanations for systematic agenda-setting differences across countries. Our straightforward categorisation in single-party and multiparty government countries highlighted significantly different responses to media attention. Systemic differences create diverging stimuli to government and opposition parties to react on media cues. Media reactivity plays out very differently for opposition and for government parties across systems. Opposition parties use the media relatively more when they have to face a single incumbent party, while government parties use the media relatively more when there are several parties in government. So, media forms a resource for politicians, but the usefulness of that resource varies across countries and across the position that one occupies in a country.

Our article is the first to provide an analysis of the interaction between media coverage and parliamentary questions in multiple Western countries. Much more can be done to expand the comparative approach of the media's role in setting the political agenda. First, we compared seven countries all with a high level of media freedom. The dynamics we found here may play out very differently under non-free media conditions. For example, when the media are not free and/or instruments of the government, it is less likely that opposition parties, if existing, would use media coverage to challenge the government in parliament. In such cases, we would expect the exact opposite: that in a particular majority 
MPs draw on the government-friendly media to put their government's great performance into the spotlight.

Second, due to the small number of countries included here, we were forced to severely limit the number of country-level variables. Making further headway would imply testing more country-level hypotheses, for example, regarding the role of the media system, executive dominance, the size of the electoral majority, the size of parliament and so on. Additionally, following earlier work focusing on government-opposition differences, we only included one party variable in our models (i.e., government/opposition). But with regard to parties as well, we suspect that more is going on. Party sizes differ, as well as the future coalition chances of parties, their ideology and professionalisation; all these factors may moderate parties' uptake of media cues.

Third, we analysed questions and found the media to matter more for the questions than vice versa. For more substantial political activities like the drafting of bills and, even more, passing legislation, the relationship might be reversed with the media rather following than driving the political agenda. Some mediatisation scholars (Strömback 2008) argue that the media logic has permeated the entire political business cycle and that politicians take the mass media into account in everything they do. Our analysis of questions seems to confirm that idea, but it remains to be seen whether the same would apply to legislating.

This brings us to the broader theoretical implications of our study. While the other 'big' theory of media and politics - the mediatisation account - shifted earlier towards analysing mediatisation in a comparative perspective, the political agenda-setting literature has so far remained a largely non-comparative undertaking. Until now, the enormous data requirements have hindered progress in this direction. Taking into account the political system in how political actors react to media cues brings entirely new things to the table. The thrust of the recent surge in political agenda-setting work has been to deepen our knowledge on political agenda-setting by specifying the exact circumstances under which the media exerts influence. Exemplifying the gradual maturation of the research field, the extant 'contingency' work is now joined by a 'broadening' literature dealing with establishing the generic character of agenda-setting by the media.

While challenging our thinking about why and how political actors adopt media cues by introducing new political system variables, it also confirms what is maybe, the key finding of the contingency literature: that political actors strategically use the media. Our complex finding of how opposition and government react differently on media coverage in different systems underscores how the media is intentionally used. Political actors employ media coverage when it fits their goals and strategy; they do not by any means blindly embrace media cues. This challenges the very notion of 'media power'. Mass media does not exert direct and 'mechanistic' influence on what political actors are doing. This recurring finding, comparatively corroborated here again, bridges the political agendasetting and mediatisation research (see also Van Aelst et al. 2014). Political actors do adapt to the media logic, but only to the extent that it is to their own advantage. Politicians' political logic serves as guidance for their selective adaptation to the media logic. 


\section{Appendix: Additional analyses}

Next to the presented models (OLS with PCSE) in the main text, all hypotheses were tested using alternative approaches. Results confirm our main findings and are discussed in detail below.

Appendix Table 1. Mutual dependencies between media and parliamentary questions (SEM model)

\begin{tabular}{|c|c|c|}
\hline & Unstandardised & Standardised \\
\hline \multicolumn{3}{|l|}{ Media attention $_{i, t}$} \\
\hline Media attention $_{\mathrm{i}, \mathrm{t}-1}$ & $0.580^{* * a k}(0.006)$ & 0.579 \\
\hline Media attention $_{\mathrm{i}, \mathrm{t}-12}$ & $0.318^{\text {wesex }}(0.006)$ & 0.317 \\
\hline Parliamentary questions $\mathrm{i}_{\mathrm{i}, \mathrm{-}} \mathrm{l}$ & $0.029^{* * * * *}(0.004)$ & 0.030 \\
\hline $\mathrm{R}^{2}$ & 0.734 & \\
\hline \multicolumn{3}{|l|}{ Parliamentary questions $\mathrm{i}_{\mathrm{i}, \mathrm{t}}$} \\
\hline Parliamentary questions $\mathrm{i}_{\mathrm{i}, \mathrm{t}-1}$ & $0.274^{\text {w*te }}(0.007)$ & 0.273 \\
\hline Parliamentary questions $s_{\mathrm{i}, \mathrm{t}-12}$ & $0.274^{* * * *}(0.007)$ & 0.279 \\
\hline Media attention $_{\mathrm{i}, \mathrm{t}-1}$ & $0.127^{* * * *}(0.007)$ & 0.125 \\
\hline $\mathrm{R}^{2}$ & 0.252 & \\
\hline Covariance (media, parliament) & & $0.067^{* * n+k}(0.007)$ \\
\hline
\end{tabular}

Notes: $\mathrm{Chi}^{2}(2)=10.16 ; \mathrm{p}=0.006 ; \mathrm{RMSEA}=0.015 ; \mathrm{CFI}=1.00 ; \mathrm{N}=17,844 .{ }^{* * * *} \mathrm{p}<0.001$.

\section{The relative strength of the influence of media on parliament, and vice versa}

We additionally rely on structural equation modelling (SEM), where we predict media attention for an issue using its own lagged value and the lagged value of questions. We also capture seasonal effects by including scores a year earlier $(\mathrm{t}-12)$.

A further check for the robustness of the findings from the OLS-PCSE and SEM-models is done by conducting two fixed effects analyses: one with media as the dependent variable and one with parliamentary questions as the dependent variable, again including lagged values at ( $\mathrm{t}-1)$ and ( $\mathrm{t}-12)$ as independent variables. In this case, all country-issue variation is removed by including dummy variables for each of those, resulting in a conservative model that deals with heterogeneity and focuses on inter-issue variation.

Appendix Table 1 presents the findings from the structural equation model. The model shows good fit statistics with the Root Mean Square Error of Approximation (RMSEA) being below 0.05 and the Confirmatory Fit Index (CFI) being higher than 0.95 . The results confirm that there is a mutual dependency of media and politics, but also that the effects of media coverage on parliamentary questions are larger than vice versa. A 1 per cent increase in question attention for an issue results in a 0.029 per cent increase in media attention in the subsequent month, while for the reversed relationship it is more than four times as much (0.127). Replication of the analysis using a pooled time-series fixed effects models confirms those findings, though the difference is slightly smaller: here we find an effect of questions on media of 0.025 and for media on questions of 0.093 . The SEM model 
Appendix Table 2. Mutual dependencies between media and parliamentary questions for opposition and coalition parties (SEM model)

\begin{tabular}{|c|c|c|}
\hline & Unstandardised & Standardised \\
\hline \multicolumn{3}{|l|}{ Media attention $_{\mathrm{i}, \mathrm{t}}$} \\
\hline Media attention $_{\mathrm{i}, \mathrm{t}-\mathrm{1}}$ & $0.565^{* * n+k}(0.006)$ & 0.565 \\
\hline Media attention $_{\mathrm{i}, \mathrm{t}-12}$ & $0.302^{*+w e n}(0.006)$ & 0.302 \\
\hline Opposition questions $_{\mathrm{i}, \mathrm{t}-1}$ & $0.027^{\operatorname{man}}(0.005)$ & 0.023 \\
\hline Government questions $\mathrm{i}_{\mathrm{i}-\mathrm{t}-1}$ & $0.017^{\text {wank }}(0.005)$ & 0.017 \\
\hline $\mathrm{R}^{2}$ & 0.667 & \\
\hline \multicolumn{3}{|l|}{ Opposition questions $_{i, t}$} \\
\hline Opposition questions $_{\mathrm{i}, \mathrm{t}-1}$ & $0.232^{\text {wenk }}(0.008)$ & 0.232 \\
\hline Opposition questions $s_{i, t-12}$ & $0.212^{* * * * *}(0.008)$ & 0.212 \\
\hline Government questions $\mathrm{i}_{\mathrm{i}-\mathrm{-}-1}$ & $0.072^{*+n k w}(0.008)$ & 0.073 \\
\hline Government questions $\mathrm{i}, \mathrm{t}-12$ & $0.113^{\operatorname{mon} n}(0.007)$ & 0.113 \\
\hline Media attention $_{\mathrm{i}, \mathrm{t}-1}$ & $0.116^{* m e n}(0.007)$ & 0.116 \\
\hline $\mathrm{R}^{2}$ & 0.247 & \\
\hline \multicolumn{3}{|l|}{ Government questions $\mathrm{i}, \mathrm{t}$} \\
\hline Government questions $_{\mathrm{i}, \mathrm{t}-1}$ & $0.149^{m+n}(0.008)$ & 0.149 \\
\hline Government questions $_{\mathrm{i}, \mathrm{t}-12}$ & $0.185^{m+n}(0.008)$ & 0.185 \\
\hline Opposition questions ${ }_{i, t-1}$ & $0.114^{* w * x}(0.008)$ & 0.114 \\
\hline Opposition questions $\mathrm{i}, \mathrm{t}-12$ & $0.129^{\text {newn }}(0.008)$ & 0.129 \\
\hline Media attention $_{\mathrm{i}, \mathrm{t}-1}$ & $0.055^{* * * *}(0.008)$ & 0.055 \\
\hline $\mathrm{R}^{2}$ & 0.174 & \\
\hline Covariance (media, opposition) & & $0.070^{\text {ness }}$ \\
\hline Covariance (media, coalition) & & $0.031^{n+m e n}$ \\
\hline Covariance (opposition, government) & & $0.272^{m+a n}$ \\
\hline
\end{tabular}

Notes: $\mathrm{Chi}^{2}(4)=17.47 ; \mathrm{p}=0.0016 ; \mathrm{RMSEA}=0.015 ; \mathrm{CFI}=0.99 ; \mathrm{N}=15,719 .{ }^{* * * *} \mathrm{p}<0.001$.

furthermore demonstrates strong autoregressive influences and that media attention is a lot better predicted than parliamentary attention $\left(\mathrm{R}^{2}\right.$ is 0.726 for media attention and 0.250 for parliamentary attention).

\section{The differential impact of media on opposition and government}

Second, we test whether effects of media on politics and vice versa differ for opposition and government parties. We again estimate a structural equation model, this time including parliamentary questions for opposition and government parties separately. In addition, we conduct fixed effects analyses with opposition and government parties as separate variables and compare the outcomes.

Results of these additional analyses can be found in Appendix Table 2, containing the results of a SEM. We first focus on media as a dependent variable. The full model, including 
lagged variables as well as seasonal effects (t-12), again shows satisfactory fit, with an RMSEA below $0.05(0.015)$ and a CFI of 0.99. Both opposition and government questions exert a significant influence on media coverage. The coefficients $(0.027$ for opposition and 0.017 for government) do not differ significantly $\left(\mathrm{Chi}^{2}(1)=0.5\right.$, df $\left.=1, \mathrm{p}=0.478\right)$. More importantly, and in line with the second hypothesis, we find that opposition parties are more affected by media attention than government parties: the effect (0.116) for opposition parties is significantly larger than for government parties $(0.055)$, with $\operatorname{Chi}^{2}(1)=40.00$, $\mathrm{p}<0.001$. Fixed effects analyses again support this conclusion: comparing coefficients from media in the equation with opposition questions as dependent variable with coefficients from media in the equation with government questions as dependent variable shows again a significant difference $(\mathrm{F}(1), 15596)=16.29, \mathrm{p}=0.000)$. We can confirm that opposition parties are more affected in their parliamentary questioning than government parties.

\section{The moderating role of a single-party government}

When looking at the moderating role of the political system, we cannot rely on fixed effects models since that would remove all variance on the country-issue level, making countrylevel variables such as the number of parties in government unusable. Thus, we re-estimate the model, this time as a three-level multilevel model that has months nested in issues that are nested in countries and estimate a cross-level interaction for single-party government (country characteristic) and media attention/parliamentary questions (per issue per month).

The multilevel model including a similar interaction term as the one reported in the main text leads to similar results, with the effect of media on questions being larger in countries with a single-party government $(0.067$ versus 0.163$)$. In contrast to the model reported in the main text, the interaction effect is significant.

\section{Notes}

1. For the United Kingdom, Prime Minister's Questions are used. In part this is due to data availability, but in general these questions are also much more comparable to the data from other countries which use questions as a form of open debate and discussion. In the United Kingdom, written and oral parliamentary questions are asked of all government ministers throughout the year totalling in the tens of thousands per year. These questions are generally much more technical and are often part of the process of debating bills.

2. In most countries this is rather straightforward, except for Switzerland. Here, we use the 'classic' distinction between governmental (FDP, CVP, SP, SVP) and nongovernmental parties (all other parties).

3. All additional analyses are available from the authors upon request.

\section{References}

Altheide, D. \& Snow, R. (1979). Media logic. Beverly Hills, CA: Sage.

Bachrach, P. \& Baratz, M. (1962). Two faces of power. American Political Science Review 56: 947-952.

Bartels, L.M. (1996). Politicians and the Press: Who Leads, Who Follows? Paper presented at the APSA conference.

Baumgartner, F. \& Chaqués-Bonafont, L. (2015). All news is bad news: Newspaper coverage of political parties in Spain. Political Communication 32: 268-291. 
Beck, N. \& Katz,J.N.(1995). What to do (and not to do) with time-series cross-section data. American Political Science Review 89: 634-647.

Blondel, J. \& Müller-Rommel, F. (eds) (1993). Governing together: The extent and limits of joint decisionmaking in Western European cabinets. New York: St Martin's Press.

Davis, A. (2007). Investigating journalist influences on political issue agendas at Westminster. Political Communication 24: 181-199.

Davis, A. (2009). Journalist-source relations, media reflexivity and the politics of politics. Journalism Studies 10: 204-219.

Edwards, G.C. \& Wood, B.D. (1999). Who influences whom? The President, Congress and the media. American Political Science Review 93: 327-344.

Esser, F. \& Strömbäck, J. (eds) (2014). Mediatization of politics: Understanding the transformation of Western democracies. New York: Palgrave Macmillan.

Green-Pedersen, C. \& Stubager, R. (2010). The political conditionality of mass media influence: When do parties follow mass media attention? British Journal of Political Science 40: 663-677.

Herbst, S. (1998). Reading public opinion: How political actors view the democratic process. Chicago, IL: Chicago University Press.

Jones, B. \& Baumgartner, F. (2005). The politics of attention: How government prioritizes attention. Chicago, IL: University of Chicago Press.

Kleinnijenhuis, J. \& Rietberg, E.M. (1995). Parties, media, the public and the economy: Patterns of societal agenda-setting. European Journal of Political Research 28: 95-118.

Lengauer, G., Esser, F. \& Berganza, R. (2012). Negativity in political news: A review of concepts, operationalizations and key findings. Journalism 13: 179-202.

Lijphart, A. (1999). Patterns of democracy. New Haven, CT: Yale University Press.

Mazzoleni, G. \& Schulz, W. (1999). Mediatization of politics: A challenge for democracy. Political Communication 16: 247-261.

Midtb $\varnothing$, T. et al. (2014). Do the media set the agenda of parliament or is it the other way around? Agenda interactions between MPs and mass media. In K. Deschouwer \& S. Depauw (eds), Representing the people: A survey among members of statewide and sub-state parliaments. Oxford: Oxford University Press.

Pritchard, D. \& Berkowitz, D. (1993). The limits of agenda-setting: The press and political responses to crime in the United States, 1950-1980. International Journal of Public Opinion Research 5: 86-91.

Saalfeld, T. (2003). Germany: Multiple veto points, informal coordination and problems of hidden action. In K. Strøm, W. Müller \& T. Bergman (eds), Delegation and accountability in parliamentary democracies. Oxford: Oxford University Press.

Semetko, H. \& Valkenburg, P. (2000). Framing European politics: A content analysis of press and television news. Journal of Communication 50: 93-109.

Soroka, S. (2002). Issue attributes and agenda-setting by media, the public and policymakers in Canada. International Journal of Public Opinion Research 14: 264-285.

Soroka, S. (2014). Negativity in democratic politics: Causes and consequences. Cambridge: Cambridge University Press.

Sprungk, C. (2010). Ever more or ever better scrutiny? Analysing the conditions of effective national parliamentary involvement in EU affairs. European Integration online Papers 14, Article 2.

Strömback, J. (2008). Four phases of mediatization: An analysis of the mediatization of politics. International Journal of Press/Politics 13: 228-246.

Thesen, G. (2013). When good news is scarce and bad news is good: Government responsibilities and opposition possibilities in political agenda-setting. European Journal of Political Research 52: 364-389.

Van Aelst, P. \& Walgrave, S. (2011). Minimal or massive? The political agenda setting power of the mass media according to different methods. International Journal of Press/Politics 16: 295-316.

Van Aelst, P. et al. (2014). Mediatization and political agenda-setting: Changing issue priorities. In F. Esser \& J. Strömbäck (eds), Mediatization of politics: Understanding the transformation of Western democracies. Basingstoke: Palgrave Macmillan.

Van Noije, L., Kleinnijenhuis, J. \& Oegema, D. (2008). Loss of parliamentary control due to mediatization and Europeanization: A longitudinal and cross-sectional analysis of agenda building in the United Kingdom and the Netherlands. British Journal of Political Science 38: 455-478. 
Vliegenthart, R. \& Mena Montes, N. (2014). How political and media system characteristics moderate interactions between newspapers and parliaments: Economic crisis attention in Spain and the Netherlands. International Journal of Press/Politics 19:318-339.

Vliegenthart, R. \& Roggeband, C. (2007). Framing immigration and integration: Relationships between press and parliament in the Netherlands. International Communication Gazette 69: 295-319.

Vliegenthart, R.\& Walgrave, S. (2011a). When media matter for politics: Partisan moderators of mass media's agenda-setting influence on parliament in Belgium. Party Politics 17:321-342.

Vliegenthart, R. \& Walgrave, S. (2011b). Content matters: The dynamics of parliamentary questioning in Belgium and Denmark. Comparative Political Studies 44: 1031-1059.

Vliegenthart, R., Walgrave, S. \& Zicha, B. (2013). How preferences, information and institutions interactively drive agenda-setting: Questions in the Belgian parliament, 1993-2000. European Journal of Political Research 52: 390-418.

Walgrave, S. (2008). Again the almighty mass media: A subjective assessment of the media's political agendasetting power by politicians and journalists in Belgium. Political Communication 25: 445-459.

Walgrave, S. \& Van Aelst, P. (2006). The contingency of the mass media's political agenda setting power: Towards a preliminary theory. Journal of Communication 56: 88-109.

Walgrave, S., Soroka, S. \& Nuytemans, M. (2008). The mass media's political agenda-setting power: A longitudinal analysis of media, parliament and government in Belgium, 1993-2000. Comparative Political Studies 41: 814-836.

Wolfe, M. (2012). Putting on the brakes or pressing on the gas? Media attention and the speed of policymaking. Policy Studies Journal 40: 109-126.

Wood, D. \& Peake, J. (1998). The dynamics of foreign policy agenda setting. American Political Science Review 92: 173-183.

Address for correspondence: Rens Vliegenthart, Department of Communication Science and Amsterdam School of Communication Research (ASCoR), University of Amsterdam, Postbus 15793, 1001 NG Amsterdam, The Netherlands. E-mail: r.vliegenthart@uva.nl 